\title{
EVALUASI PROGRAM GERAKAN FURUDHUL AINIYAH (GEFA) DENGAN MENGGUNAKAN MODEL KIRKPATRICK
}

\author{
Ali Ridho \\ Institut Agama Islam (IAI) Al- Khairat Pamekasan \\ Aldo.okfor@gmail.com \\ Kusaeri \\ Universitas Islam Negeri (UIN) Sunan Ampel Surabaya \\ kusaeri@uinsby.ac.id \\ Nasaruddin \\ Institut Agama Islam (IAI) Muhammadiyah Bima \\ nasarhb@gmail.com \\ Fathur Rohman \\ Universitas Islam Nahdlatul Ulama (Unisnu) Jepara \\ fathur_rohman@unisnu.ac.id
}

\begin{abstract}
This study discusses the Gerakan Furudul Ainiyah (GEFA) which was conducted in Madrasah of East Java. To value its effectiveness, a comprehensive evaluation of the program and the process of program implementation needs to be conducted, and different evaluations need to be approved. There are several models that can be used to measure the effectiveness of the programs and the implementation processes such as the CIPP model, Stake Countenance, and the others. This study offers a program evaluation model that is the Kirkpatrick model that will evaluate in deeply levels, with four levels namely reaction levels, impact program level, learning change level and outcome level. From those various levels, they are equipped with instruments of assessment.
\end{abstract}

Keyword: GEFA, evaluation, krikpatrick

\begin{abstract}
Abstrak
Penelitian ini membahas tentang Gerakan Furudul Ainiyah (GEFA) yang dilaksanakan di Madrasah Jawa Timur. Untuk menilai keefektifannya, evaluasi program yang komprehensif dan proses pelaksanaan program perlu dilakukan, dan evaluasi yang berbeda perlu disetujui. Ada beberapa model yang dapat digunakan untuk mengukur efektivitas program dan proses implementasi seperti model CIPP, Stake Countenance, dan lain-lain. Penelitian ini menawarkan model evaluasi program yaitu model Kirkpatrick yang akan dievaluasi secara mendalam, dengan empat tingkatan yaitu tingkat reaksi, tingkat dampak program, tingkat perubahan pembelajaran dan tingkat hasil. Dari berbagai level tersebut, mereka dilengkapi dengan instrumen penilaian.
\end{abstract}

Kata Kunci: GEFA, evaluasi, krikpatrick 


\section{Pendahuluan}

Gerakan Furudhul Ainiyah (GEFA) merupakan bagian dari Gerakan Ayo Membangun Madrasah (GERAMM) yang diinisiasi oleh Kementerian Agama Provinsi Jawa Timur, sekaligus menjadi program unggulan yang disosialisasikan serta di assesment oleh Kementerian melalui pengawas madrasah secara bertahap ${ }^{1}$. Keberadaan GEFA tidak lepas dari karakteristik dan tujuan PAI di Madrasah yakni setiap lulusan madrasah memiliki kemampuan holistik dan implementatif baik dari aspek sikap, pengetahuan dan aspek keterampilan tentu sesuai dengan tingkatannya masing-masing. ${ }^{2}$

Munculnya gerakan ini dilatar belakangi adanya masalah pada implementasi Pendidikan Agama Islam di Madrasah, yaitu tidak tercapainya tujuan pembelajaran PAI. ada beberapa indikator yang menunjukkan belum tercapainya tujuan PAI di Madrasah ${ }^{3}$, yaitu 1) Aspek afektif, lulusan Madrasah belum memiliki sikap spiritual dan sikap sosial yang diharapkan. 2) Aspek kognitif, nilai rata-rata UAMBD dan UAMBN masih di bawah standar. 3) Aspek Psikomotor, sebagian lulusan Madrasah belum terampil melakukan sesuatu yang dipelajari di Madrasah, seperti praktik baca tulis al-Qur'an, wudhu, shalat dan praktik ibadah lainnya. Disamping Undang-undang yang secara eksplisit menjelaskan tentang tujuan pendidikan yang mengarah pada kompetensi tiga komponen tersebut baik kognitif, afektif dan psikomotorik juga beberapa penelitian faktual menunjukkan keharusan adanya keterkaitan ketiga komponen tersebut agar tujuan pendidikan bisa tercapai. ${ }^{4}$ untuk mewujudkan tiga kemampuan tersebut apalagi mata pelajaran PAI yang bersentuhan langsung dengan aktivitas sehari-hari sebagai individu untuk berinteraksi dengan tuhan dan sebagai makhluk sosial dalam bermuamalah.

Terdapat beberapa faktor yang menyebabkan terjadinya gap antara tiga kemampuan ini. Pertama, profesionalisme guru. Proses pembelajaran dengan sasaran siswa harus benar-benar dipersiapkan oleh guru dengan berbagai persiapan untuk mencapai level profesional ${ }^{5}$. Menurut Kennedy profesional tercermin dari materi yang harus dipelajari guru dan strategi bagaimana guru menyampaikannya ${ }^{6}$. metode pembelajaran, media pembelajaran serta strategi pembelajaran.

\footnotetext{
${ }^{1}$ Tim Pengembangan GERAMM, Buku Panduan Khusus Program Gerakan Ayo Membangun Madrasah.

2 Rovai et al., "Development of an Instrument to Measure Perceived Cognitive, Affective, and Psychomotor Learning in Traditional and Virtual Classroom Higher Education Settings."

${ }^{3}$ Tim Pengembangan GERAMM, Buku Panduan Khusus Program Gerakan Ayo Membangun Madrasah.

${ }^{4}$ Enneking et al., "The Evaluation of a Hybrid, General Chemistry Laboratory Curriculum."

${ }^{5}$ Osman and Warner, "Measuring Teacher Motivation."

${ }^{6}$ Kennedy, "How Does Professional Development Improve Teaching?"
} 
Sebagai tolak ukur dari kesuksesan sebuah program, maka perlu adanya evaluasi yang komprehensif, disamping untuk keperluan formal juga diperlukan untuk mengukur sejauh mana tujuan pembelajaran bisa tercapai dengan baik ${ }^{7}$. Melihat karakteristik program Furudhul Ainiyah terdapat beberapa model evaluasi yang yang bisa diimplementasikan supaya Gerakan Furudhul Ainiyah yang merupakan bagian dari program unggulan Kementerian Agama Provinsi Jawa Timur dengan harapan bisa berjalan dengan baik, efektif dan efisien ${ }^{8}$.

Pertama, evaluasi model CIPP (Context, Input, Process and Product) sebuah model yang dimunculkan oleh Stufflebeam dan menekankan pada perbaikan program ${ }^{9}$. Menurutnya, evaluasi bukan sarana pembuktian program namun upaya perbaikan pada arah yang lebih baik. Context evaluation berupaya melihat secara mendalam dan menyeluruh terkait problem yang dihadapi, orientasinya adalah memberikan masukan dan meluruskan ketika proses yang dilakukan tidak mengarah pada tujuan yang diharapkan. Input evaluation menjadi penentu terhadap bagaimana tujuan bisa dicapai. Process evaluation, memastikan proses sesuai dengan rencana dan waktu berjalan sesuai jadwal. Product evaluation, memberikan pertimbangan untuk keberlanjutan program ${ }^{10}$.

Kedua, evaluasi model Stake countenance ${ }^{11}$ sebuah model evaluasi yang munculkan oleh Robert Stake sebagai kreator yang mempunyai tiga tahapan dalam implementasinya yaitu tahap antecedent upaya mendapatkan informasi terkait perilaku sebelum program dilaksanakan apakah nantinya berdampak atau menjadi penghalang dari suksesnya program. Tahap transaction bagaimana pelaksanaan sesuai dengan rencana, dan outcome produk dari program ${ }^{12}$.

Ketiga, Kirkpatrick evaluation model. Sebuah model evaluasi yang menguji efektivitas program baik pada level 1, 2, 3 dan 4 yang dilakukan secara objektif ${ }^{13}$ sehingga program dirasakan manfaatnya. Level 1 akan melihat reaksi siswa dalam merespon program, yang terlaksana melalui kegiatan intrakurikuler yaitu dimana setiap siswa wajib mengikuti dengan jadwal yang terstruktur demi meningkatkan Standar Kompetensi

\footnotetext{
${ }^{7}$ Ewell, "Accreditation and Student Learning Outcomes: A Proposed Point of Departure."

${ }^{8}$ Bers, "The Role of Institutional Assessment in Assessing Student Learning Outcomes."

${ }^{9}$ Hasan, Yasin, and Yunus, "A Conceptual Framework for Mechatronics Curriculum Using Stufflebeam CIPP Evaluation Model."

${ }^{10}$ AbdiShahshahani et al., "The Evaluation of Reproductive Health PhD Program in Iran."

${ }^{11}$ Thanabalan, Siraj, and Alias, "Evaluation of a Digital Story Pedagogical Module for the Indigenous Learners Using the Stake Countenance Model."

${ }^{12}$ Fatima et al., "Early Childhood Special Education Program at the Outcome Phase."

13 Praslova, "Adaptation of Kirkpatrick's Four Level Model of Training Criteria to Assessment of Learning Outcomes and Program Evaluation in Higher Education."
} 
Lulusan melalui Kompetensi Dasar. Level 2 dampak pembelajaran yang bisa mengembangkan kompetensi siswa secara kognitif afektif dan psikomotorik. Level $3^{14}$ behavior perubahan perilaku siswa saat kembali ke masyarakat. level 4 result atau hasil akhir dari proses yang dilakukan ${ }^{15}$

Ketiga contoh model evaluasi tersebut sama-sama bisa digunakan untuk mengevaluasi program pendidikan yang dilaksanakan oleh lembaga pendidikan untuk melihat sejauh mana efektifitas program, namun demikian terdapat kelebihan dan kekurangan dari masing-masing model evaluasi ini. Yang pertama model CIPP (Context, Input, Process and Product) merupakan model yang sangat kompleks namun terlalu menekankan pada proses Top down sehingga kurang memperhatikan terhadap fleksibilitas masalah yang terjadi di lapangan, untuk diterapkan pada program Gerakan Furudhul Ainiyah $^{16}$. Kedua, evaluasi model Stake countenance, model yang sangat kompleks ini dirasa terlalu rumit ketika harus menghubungkan dengan program lain yang diterapkan sebelumnya. Yang ketiga Kirkpatrick evaluation model juga merupakan model yang sangat kompleks bahkan cenderung sangat rumit terutama ketika harus masuk pada level 3 dan $4^{17}$. Namun demikian, ketika melihat program Furudhul Ainiyah yang lebih menekankan pada aspek afektif dan psikomotorik maka model yang ketiga lebih memungkinkan untuk diterapkan.

Tulisan ini akan membahas tentang program Furudhul Ainiyah yang mengintegrasikan semua aspek, baik kognitif, aspek sikap dan psikomotor serta pembiasaan dengan aspek keteladanan dalam penyelenggaraan PAI di Madrasah, yaitu Gerakan Furudhul Ainiyah (GEFA) salah satu komponen dari program Gerakan Ayo Membangun Madrasah (GERAMM).untuk mengevaluasi efektivitas program ini akan digunakan Kirkpatrick Evaluation Model yang menjadi pokok bahasan artikel ini.

\section{Gerakan Furudhul Ainiyah}

Gerakan Furudhul Ainiyah, merupakan gerakan madrasah yang bertujuan untuk membentuk peserta didik sebagai individu yang berkarakter dan berkepribadian Islami ${ }^{18}$.

\footnotetext{
14 Terdapat perbedaan mendasar antara hasil dari penilaian pada level 2 dan pada penilaian level 3 . Perubahan pada level 2 lebih pada perubahan disaat program pembelajran dilaksanakan, sedangkan pada level 3 perubahan yang tercermin setelah program selesai dan kembali kepada masyarakat.

${ }^{15}$ Smidt et al., "The Kirkpatrick Model."

${ }^{16}$ Roselita Yusof, "Kelebihan Dan Kelemahan Model CIPP."

${ }^{17}$ Reio et al., "A Critique of Kirkpatrick's Evaluation Model."

18 Tim Pengembangan GERAMM, Buku Panduan Khusus Program Gerakan Ayo Membangun Madrasah.
} 
Tujuan program ini senada dengan tujuan pendidikan dalam Undang-undang Sistem Pendidikan Nasional dalam upaya menciptakan generasi unggul dan berkarakter ${ }^{19}$. Istilah Furudhul Ainiyah berasal dari kata Furudhul dan Ainiyah. Furudhul diambil dari kata fardhu yang berarti kewajiban sedangkan ainiyah diambil dari kata 'ain yang berarti individual. Dengan demikian, secara harfiah Furudhul Ainiyah berarti kewajibankewajiban yang bersifat individual ${ }^{20}$.

Program Gerakan Furudhul Ainiyah terprogram di bawah naungan Kementerian Agama Provinsi Jawa Timur dengan berlandaskan pada pola aturan hukum yang jelas, mulai dari Undang-Undang, Peraturan Pemerintah, Peraturan Menteri Agama dan Surat Edaran Kepala Kantor Wilayah Kementerian Agama Provinsi Jawa Timur. Mengingat urgennya program ini termasuk aturan yang jelas maka harus terdapat upaya untuk memastikan program ini berjalan dengan baik. ${ }^{21}$ yang hal ini dikendalikan oleh pengawas Madrasah Kabupaten.

Program Gerakan Furudhul Ainiyah harus mempunyai tujuan pelaksanaan yang baik, mengingat program ini menjadi solusi dari adanya gap antara tujuan dan hasil. Pertama, Mengembangkan blueprint GEFA dengan meletakkan makna dan nilai utama sebagai generator utama dalam penyelenggaraan pendidikan ${ }^{22}$. kedua, membangun dan membekali peserta didik madrasah sebagai generasi emas Idonesia $2045^{23}$ menghadapi dinamika perubahan di masa depan dengan keterampilan abad 21 dengan nilai-nilai Furudhul ainiyah. Ketiga, Menjadikan Furudhul Ainiyah sebagai ruh dan fondasi pendidikan ${ }^{24}$ melalui harmonisasi olah hati (etik dan spritual), olah rasa (estetik), olah pikir (literasi dan numerasi), dan olah raga (kinestetik). Keempat, Merevitalisasi dan memperkuat kapasitas ekosistem pendidikan (kepada madrasah, guru, peserta didik, pengawas dan momite madrasah) untuk mendukung implementasi GEFA. Kelima, Membangun jejaring pelibatan masyarakat (publik) sebagai sumber-sumber belajar di dalam dan di luar madrasah

Implementasi program Furudhul Ainiyah harus sesuai dan sinkron dengan tujuan program yang ingin dicapai, hal ini bisa dilakukan dengan beberapa cara mulai dari analisis kompetensi dasar dan identifikasi nilai-nilai karakter. Mendesai rencana studi untuk menguatkan implementasi nilai-nilai karakter pada siswa dengan riil sehingga siswa

\footnotetext{
19 "UU No.20 Thn 2003 - Sistem Pendidikan Nasional."

20 Tim Pengembangan GERAMM, Buku Panduan Khusus Program Gerakan Ayo Membangun Madrasah.

${ }^{21}$ Sandifer et al., "Factors Associated with Programmatic Orientation and Supervision in Schools."

${ }^{22}$ Sesuai dengan tujuan pendidikan sebagai leading sektor pengembangan sumber daya manusia

${ }^{23}$ Rokhman et al., "Character Education for Golden Generation 2045 (National Character Building for Indonesian Golden Years)."

${ }^{24}$ Griffin and McDougall, "Despite Ourselves? Education Studies: Between Spirit and 'Passing On.'”
} 
mendapatkan dampak yang positif dari proses yang dilakukan. Pengayaan dalam metodologi juga sangat relevan untuk dipertinbangkan dalam iplementasi program serta dikuatkan dengan evaluasi yang objektif. ${ }^{25}$

Sebagai sebuah contoh implemntasi program Furudhul Ainiyah yang bisa diterapkan pada siswa Kelas XI Semaster Genap bidang al-Qur'an, maka pertanyaan terbesarnya adalah kecakapan apa yang ingin dicapai? Apa saja kegiatannya untuk mencapai tujuan tersebut hal ini perlu diurai langkah-langkahnya serta waktunya ${ }^{26}$.

\begin{tabular}{|c|c|c|c|c|}
\hline \multirow{4}{*}{$\begin{array}{l}\text { Bidang } \\
\text { Akidah } \\
\text { Akhlak }\end{array}$} & \multirow[t]{2}{*}{ Kecakapan } & \multicolumn{2}{|c|}{ Kegiatan } & \multirow{3}{*}{$\begin{array}{c}\text { Waktu } \\
\text { Satu Semester }\end{array}$} \\
\hline & & Ko/Ekstra & Uraian & \\
\hline & Mampu menjelaskan & Kokurikuler & & \\
\hline & dan mempraktekkan: & & & \\
\hline & $\begin{array}{l}\text { 1. Adab } \\
\text { memberi dan } \\
\text { menjawab } \\
\text { salam }\end{array}$ & & Simulası & \\
\hline & $\begin{array}{l}\text { 2. Adab } \\
\text { mengundang } \\
\text { dan menerima } \\
\text { undanagan }\end{array}$ & & Simulai & \\
\hline & $\begin{array}{l}\text { 3. Adab } \\
\text { pergaulan pria } \\
\text { dan wanita }\end{array}$ & & Praktik & \\
\hline & $\begin{array}{l}\text { 4. Adab makan } \\
\text { dan minum }\end{array}$ & & Simulasi & \\
\hline
\end{tabular}

Tabel 1

Contoh Rencana Pembelajaran

\section{Kirkpatrick Evaluation Model}

Banyak pilihan model evaluasi yang dapat diterapkan dalam menilai seberapa efektif program Furudhul Ainiyah diterapkan di madrasah. Mulai dari model CIPP (Context, Input, Process and Product), evalusi model Stake's countenance maupun Kirkpatrick evaluation model. Berbagai model evaluasi tersebut sama-sama mengukur efektifitas program walaupun dengan mekanisme yang berbeda terutama jika diterapkan para evaluasi terhadap program Furudhul Ainiyah.

Context, Input, Process and Product (CIPP) evaluation model jika diterapkan pada program Furudhul Aniyah dalam format sederhana maka bisa digambarka sebagai

\footnotetext{
${ }^{25}$ Hidalgo and Arjona Fuentes, "The Development of Basic Competencies for Sustainability in Higher Education: An Educational Model by Luis Hidalgo, Juan Arjona Fuentes :: SSRN."

26 Tim Pengembangan GERAMM, Buku Panduan Khusus Program Gerakan Ayo Membangun Madrasah.
} 
berikut $^{27}$ : pertama, menggali secara mendalam tujuan dari pelaksanaan GEFA, ketika faktor keberadaannya disebabkan terjadinya gap antar tujuan dan hasil dalam pelajaran PAI maka tujuan sesungguhnya dari GEFA ini adala menghilangkan gap tersebut. Kedua, melanjutkan dari konteks tujuan maka selanjutnya menentukan bagaimana prosedur untuk mencapainya, baik dari segi SDM maupun metode dan strategi. Program GEFA harus dilakukan sosialisasi secara menyeluruh termasuk bagaiman teknis implementasinya, semakin siap SDM dalam menjalankan program maka semakin baik proses yang dilaksanakan, kondisi ini yang harus diperhatikan dalam melakukan evaluasi GEFA. Ketiga, proses untuk mencapai tujuan dengan berbagai prosedur yang dijalankan, evaluasi ini untuk merekam dan mengedentifikasi bagaimana teknis tersebut berjalan dengan efektif dan efesien. Keempat, produk sebagai hasil akhir menjadi titik tolak apakah semua prosedur berjalan dengan baik sehingga hasil sesuai dengan tujuan ${ }^{28}$.

Evalusi model Stake's countenance, dalam evaluasi ada dua hal pokok yang menjadi titik tekan dalam pelaksanaannya, yaitu; deskripsi dan pertimbangan. Sedangkan berkaitan dengan realisasi program evaluasinya yaitu; Anteceden (konteks awal), Transaksi (Proses), dan Hasil (outcome). Anteceden mengakji kegiatan-kegitan terkait yang dilaksanakn sebelum program GEFA, hal ini penting untuk memastikan capaian dari masing-masing program yang dijalankan. Transaksi merupakan proses pelaksaaan dan outcome sebagai produk dari proses ${ }^{29}$.

Kirkpatrick merupakan salah seorang ahli evaluasi program pelatihan dalam bidang pengembangan sumber daya manusia (SDM). Model evaluasi yang dikembangkan oleh Kirkpatrick dikenal dengan istilah Kirkpatrick Four Levels Evaluation Model. Evaluasi terhadap efektivitas program pelatihan (training) menurut Kirkpatrick (1998) mencakup empat level evaluasi, yaitu: level 1 reaction, level 2 learning, level 3 behavior, dan level 4 result $^{30}$, dari nama tersebut dibuatlah nama model penilaian sehingga menjadi identitas yang melekat kepada penciptanya.

Program Garakan Furul Ainiyah yang berbasis pada pengembangan dan peningkatan kemampuan kognitif, afektif dan psikomotorik siswa menjadi menarik ketika dilakukan evaluasi dengan menggunakan model Kirkpatrick. karena disamping tidak pernah

\footnotetext{
${ }^{27}$ Aziz, Mahmood, and Rehman, "Implementation of CIPP Model for Quality Evaluation at School Level."

${ }^{28}$ Zhang et al., "Using the Context, Input, Process, and Product Evaluation Model (CIPP) as a

Comprehensive Framework to Guide the Planning, Implementation, and Assessment of Service-Learning Programs."

${ }^{29}$ Thanabalan, Siraj, and Alias, "Evaluation of a Digital Story Pedagogical Module for the Indigenous Learners Using the Stake Countenance Model."

${ }^{30}$ Donald L Kirkpatrick and James D Kirkpatrick, Evaluating Training Programs.
} 
dilakukan sebelumnya, juga sangat memungkinkan untuk dilakukan penilaian secara konprehensip untuk semua kategori Kirkpatrick Evaluation Model, karena basis program GEFA ini berkaitan betul dengan amaliyah (afektif \& psikomotorik) siswa dalam beragama. Maka dari itu perlu adanya Komitmen penilaian yang serius dan objektif untuk dilakukan demi mencapai sebuah kepastian dari kondisi yang sebelumnya masih $\operatorname{abstrack}^{31}$.

\section{Level 1 (Reaction)}

Penilaian Furudhul Ainiyah pada level 1 ini bagaimana melihat reaksi siswa terhadap program, hal ini menjadi feedback bagi steakholder pendidikan apakah program tersebut baik ataupun kurang baik dalam implementasi maupun strateginya ${ }^{32}$. Pada tingkat reaksi ini minimal ada dua indikator yang dapat digunakan, yaitu seberapa banyak siswa mendapatkan manfaat dari program dan dimensi utilitas yaitu seberapa banyak yang siswa peroleh dari program ini ${ }^{33}$.

Pada penilaian level 1 ini Gerakan Furudhul Ainiyah dapat dilihat dalam manajemen kelas $^{34}$, bagaimana aktivitas siswa dapat mencerminkan adanya reaksi positif. Paull mengistilahkan sebagai respon bahagia dan senyum dari siswa ${ }^{35}$ adapun respon tersebut terciptanya sebuah tujuan pembelajaran sebagai berikut: Pertama, Tumbuhnya nilai saling menghargai dan toleran. Respon ini bisa dilihat dengan melihat bagaimana siswa menjadi pendengar yang baik atau menyimak saat guru memberikan penjelasan di dalam kelas. Kedua, Tumbuhnya sikap percaya diri siswa. Hal ini bisa dilihat saat bertanya dengan mengacungkan tangan saat terdapat materi yang kurang dipahami. Ketiga, Kuatnya nilai disiplin, tanggung jawab dan komitmen diri. Diwujudkan dengan kesiapan siswa dalam menerima sanksi saat melanggar, lambat datang ke kelas atau tidak mengerjakan pekerjaan rumah.

Penilaian reaksi belajar siswa ini merupakan proses pengumpulan informasi terkait reaksi peserta dalam melaksanakan proses pembelajaran, dari informasi tersebut digali dengan menggunakan instrumen-instrumen baik dengan metode kualitatif maupun kuantitatif. Tujuannya adalah untuk mengetahui dua hal yaitu tentang apa yang dipelajari

\footnotetext{
${ }^{31}$ Adom, Mensah, and Dake, "Test, Measurement, and Evaluation."

32 Arthur et al., "Teaching Effectiveness."

33 Aryadoust, “Adapting Levels 1 and 2 of Kirkpatrick's Model of Training Evaluation to Examine the Effectiveness of a Tertiary-Level Writing Course."

34 Tim Pengembangan GERAMM, Buku Panduan Khusus Program Gerakan Ayo Membangun Madrasah.

35 Paull, Whitsed, and Girardi, “Applying the Kirkpatrick Model: Evaluating an Interaction for Learning Framework Curriculum Intervention."
} 
siswa dari proses belajar dan apa dampak yang dapat mereka dapatkan dari apa yang sudah dipelajari. Hasil dari proses ini untuk meningkatkan pembelajaran lanjutan ${ }^{36}$. Dengan langkah ini diharapkan akan benar-benar terukur secara objektif hasil dari proses pembelajaran ${ }^{37}$, bahkan reaksi tersebut dapat digambarkan dengan pengetahuan yang meningkat, dan psikomotoriknya berkembang sebagai konsekwensi dari pelaksanaan $\operatorname{program}^{38}$.

Menurut Kirkpatrick mengukur reaksi penting dilakukan, hal ini untuk memiliki data nyata bahwa reaksi menguntungkan tidak hanya sekedar informasi sepihak dari pembimbing maupun dari peserta. Minat, perhatian, dan motivasi peserta banyak berhubungan dengan pembelajaran yang terlaksana. Disamping itu yang menjadi pengingat bagi pengelola pembelajaran, bahwa peserta didik adalah pelanggan, dan kepuasan pelanggan sangat terkait dengan aktifitas yang berkelanjutan ${ }^{39}$.

\section{Level 2 (Learning)}

Level 2 Kirkpatrick sebagai model penilaian dari program Gerakan Furudhul Ainiyah di madrasah untuk mengukur pengetahuan yang diperoleh, sikap dan keterampilan yang berubah karena mengikuti program ${ }^{40}$. Menurut Richard (2015) level 2 dalam rangka menjawab dari apa yang didapatkan peserta dengan pengalaman pendidikan, ${ }^{41}$ hal ini menggambarkan bahwa Kirkpatrick mempunyai prinsip dinamis dalam proses seakan tidak celah sedikitpun untuk hanya sekedar jalan di tempat (satgna) langkah operasional dari satu posisi ke posisi yang lain. Sehingga menurutnya, pada level 2 ini proses penilaian harus merespon dari pengetahuan, sikap dan keterampilan siswa sebagai feedback dari evaluasi program.

Berbagai metode dapat diterapkan pada level ini, termasuk wawancara, tes, analisis berdasarkan iventaris dan survey ${ }^{42}$, tentunya setelah pelaksanaan program, namun menurut Kirkpatrick yang menjadi pertanyaan mendasar dalam rangka mengetahui level belajar ini,

\footnotetext{
${ }^{36}$ Wang and Chang, "Student Learning Outcome Assessment for an Information Organization Curriculum Based on the Kirkpatrick Framework."

${ }^{37}$ Praslova, "Adaptation of Kirkpatrick's Four Level Model of Training Criteria to Assessment of Learning Outcomes and Program Evaluation in Higher Education."

${ }^{38}$ Farjad, "The Evaluation Effectiveness of Training Courses in University by Kirkpatrick Model (Case Study."

${ }^{39}$ Donald L Kirkpatrick and James D Kirkpatrick, Evaluating Training Programs.

${ }^{40}$ Wang and Chang, "Student Learning Outcome Assessment for an Information Organization Curriculum Based on the Kirkpatrick Framework."

${ }^{41}$ Gunderman and Chan, "Kirkpatrick's Evaluation of Educational Programs and Its Relevance to Academic Radiology."

${ }^{42}$ Stamm, Harlow, and Walls, "An Introduction to Latent Variable Growth Curve Modeling."
} 
yaitu $^{43}$ : Pengetahuan apa yang dipelajari dari program GEFA?, Keterampilan apa yang dikembangkan atau ditingkatkan melalui program GEFA? Dan Sikap apa yang dirubah disebabkan program GEFA?

Pertanyaan ini penting karena akan berkaitan langsung dengan level selanjutnya, secara kasat mata tidak mungkin tercipta sebuah perubahan ketika tidak terlaksana sebuah proses pembelajaran yang baik. Terlaksananya proses itu bisa diketahui ketika tercipta sebuah perubahan pengetahaun, sikap dan keterampilan siswa setelah mengikuti program ${ }^{44}$. Perubahan pada level ini berbeda pada perubahan level 3 yang lebih luas jangkauannya. Maka menurut Tian (2015) sebagaimana yang telah dia praktekkan dalam penelitiannya untuk mengetahui dengan jelas perubahan tersebut bisa dilakukan tes sebelum dan setelah pelaksanaan program sehingga bisa diukur kemampuan siswa ${ }^{45}$.

Level 2 tetap menjadi level paling populer yang digunakan untuk mengevaluasi program pendidikan dan pelatihan ${ }^{46}$. Walau secara praktik pengukurannya lebih sulit dan memakan waktu daripada pengukuran reaksi. Menurut Kirkpatrick pedoman untuk Mengevaluasi Pembelajaran bisa memperhatikan hal berikut; ${ }^{47}$ Gunakan grup kontrol jika sifatnya praktis karena hal ini akan mempermudah implementasinya. Mengevaluasi pengetahuan, keterampilan, dan / atau sikap sebelum dan sesudah program, sehingga diketehaui perkembangan siswa dari fase ke fase yang lain. Menggunakan tes kertas dan pensil untuk mengukur pengetahuan dan sikap karena lebih menunjukkan objektifitasnya. menggunakan tes kinerja untuk mengukur keterampilan dan harus berusaha untuk mendapatkan respons 100 persen dari peserta.yang terakhir menggunakan hasil evaluasi untuk mengambil tindakan lebih lanjut yang sesuai dan proporsional.

\section{Level 3 (Behavior)}

Penilaian program Furudhul Ainiyah pada level ini melihat sejauh mana siswa menerapkan pengetahuan, sikap dan keterampilan yang telah diperolehnya di madrasah saat keluar dari madrasah. Kriteria perilaku juga disebut sebagai kriteria transfer, perubahan terminologi yang diusulkan oleh Alliger et al. (1997). Tingkat ini mencakup ukuran kinerja aktual di tempat siswa berasal dan dapat digunakan untuk mengidentifikasi

\footnotetext{
${ }^{43}$ Donald L Kirkpatrick and James D Kirkpatrick, Evaluating Training Programs.

${ }^{44}$ Ömer Gökhan ULUM, "Program Evaluation through Kirkpatrick’s Framework."

45 Tian et al., "Evaluation of Simulation-Based Training for Aircraft Carrier Marshalling with Learning Cubic and Kirkpatrick's Models."

${ }^{46}$ Reio et al., "A Critique of Kirkpatrick's Evaluation Model."

${ }^{47}$ Donald L Kirkpatrick and James D Kirkpatrick, Evaluating Training Programs.
} 
dampak program Furudhul Ainiyah terhadap prilaku siswa ${ }^{48}$. Pada tahapan ini benar-benar melihat dampak faktual dari prilaku peserta didik setelah keluar dari madrasah sebagai tempat siswa dalam mengembangkan kognitif, akektif serta psikomotoriknya.

Idealnya, kriteria pembelajaran dan kriteria perilaku secara konseptual harusnya saling berkaitan, penelitian telah menemukan hubungan yang relatif sederhana antara keduanya, yang mana biasanya dikaitkan dengan fakta bahwa lingkungan pasca-pelatihan bisa saja tidak memberikan peluang bagi peserta didik untuk menerapkan materi atau keterampilan yang dipelajarinya ${ }^{49}$. Kondisi ini menjadi permasalahan tersendiri bagi terlaksanya proses penilaian program melalui model penilaian Kirkpatrick ini. Kondisi ini jugalah yang banyak mendapatkan kritik ${ }^{50}$ dari model evaluasi Krikpatrick dikarenakan sulit menjangkau pada level 3 dan $4^{51}$.

Menurut Kirkpatrick, untuk melakukan penilaian pada level 3 ini, ada beberapa Pedoman evaluasi prilaku yang harus diperhatikan yaitu : menggunakan grup sebagai kontrol jika sifatnya praktis, memberikan waktu untuk perubahan perilaku yang terjadi, mengevaluasi sebelum dan sesudah program jika hal itu dimungkinkan, dan melakukan Survei dan / atau wawancarai satu atau lebih dari peserta program Furudhul Ainiyah, semakin banyak informan maka akan semakin baik pula informasi yang di dapatkan ${ }^{52}$.

Pada level 3 penilaian dengan Kirkpatrick model ini menjadi feedback bagi efektifitas pelaksanaan program, walaupun tidak terdapat standar pencapaian minimal dari output pelaksanaan ini, namun cukup adanya perubahan yang lebih baik dari sebelum mengikuti program ${ }^{53}$. Pengumpulan data bisa dengan kuesioner, wawancara maupun keduanya secara bersamaan. Adapun contoh instrumen wawancaranya adalah ${ }^{54}$; Apakah saudara melakukan sesuatu yang berbeda pada aktivitas karena saudara mengikuti program madrasah, dalam hal ini Furudhul Ainiyah? Jika jawabannya ya, tanyakan, Bisakah

\footnotetext{
${ }^{48}$ Alliger et al., "A Meta-Analysis of the Relations Among Training Criteria."

49 Arthur et al., "Teaching Effectiveness."

${ }^{50}$ Reio et al., "A Critique of Kirkpatrick's Evaluation Model."

${ }^{51}$ Bagaimana dengan program Furudhul Ainiyah? Maka berdasarkan instrumen materi ajar yang sudah tertata dalam buku panduan, menurut hemat penulis sangat relevan dilakukan penilaian dengan menggunakan Kirkpatrick evaluation Model, hal ini tidak lepas karena konten program yang sangat melekat dengan prilkau keseharian siswa madrasah dan menjadi karakter yang melekat pada mereka. Konten tersebut meliputi al-Qur'an Hadis, Fiqh Mua'malah, Akhlakul Karimah dan keimanan. Selain itu, GEFA sangat responsif terhadap kondisi kekinian, hal ini tertuang dalam prinsip GEFA meliputi prinsip spritual, moderasi Islam, universal, terintegrasi, partisipatif, kearifan lokal, kecakapan abad 21, adil dan inklusif, selaras dengan perkembangan peserta didik dan terukur (Buku Panduan GERAMM)

${ }^{52}$ Donald L Kirkpatrick and James D Kirkpatrick, Evaluating Training Programs.

${ }^{53}$ Razanaufal and Lantu, "Evaluation of Leadership Training Program Using Kirkpatrick Model Case Study in Telkom Corporate University."

${ }^{54}$ Donald L Kirkpatrick and James D Kirkpatrick, Evaluating Training Programs.
} 
saudara jelaskan secara singkat apa yang saudara lakukan dan bagaimana dampaknya? Jika saudara tidak melakukan sesuatu yang berbeda, dapatkah saudara memberi tahu saya alasannya? Apakah itu karena saudara tidak mempelajari apa pun yang dapat saudara gunakan di lingkungan hidup saudara? Apakah orang tua/sesepuh saudara mendorong saudara untuk mencoba hal-hal baru, atau apakah orang tua/sesepuh saudara tidak mendorong perubahan perilaku saudara? Apakah saudara berencana untuk mengubah perilaku saudara di masa depan? Jika jawabannya ya, tanyakan, Apa yang saudara rencanakan sesuatu yang berbeda tersebut?

\section{Level 4 (Result)}

Evaluasi Kirkpatrick level 4 adalah kriteria hasil yang mana poin ini merupakan substansi dari pelaksanaan pembelajaran ketika berkaitan dengan organisasi ${ }^{55}$. Makanya Evaluasi peringkat ini juga disebut sebagai kinerja organisasi di mana pengukuran dampak jangka panjang dan hasil tidak langsung dari pelatihan yang diukur seperti perubahan kinerja diri, organisasi, dan pelanggan setelah pelatihan dilakukan. menyimpulkan bahwa penilaian hasil ini difokuskan pada hasil, karena peserta telah mengikuti $\operatorname{program}^{56}$. Penilaian dibuat untuk mengevaluasi perubahan dalam kinerja organisasi, seperti membandingkan kualitas dan kuantitas hasil kerja dan jam kerja, sebelum dan sesudah pelatihan. Beberapa program bertujuan untuk meningkatkan pekerja dan membangun kerja tim yang lebih baik. Dengan kata lain, penilaian tingkat ini adalah penilaian dampak dari program di organisasi ${ }^{57}$

Dalam konteks program Furudhul Ainiyah, organisasi siswa bisa merupakan wujud dari asal daerah, madrasah atau skop yang paling kecil yaitu keluarga siswa. Adakah dampak yang signifikan bagi lingkungan siswa atas keikutsertaan siswa (siswa belajar di madrasah), inilah titik poin penting bagi siswa bahwa hidupnya bukan hanya semata-mata untuk kepentingan dirinya secara pribadi, namun juga untuk lingkungan sosialnya. Keberadaan asrama juga bisa menjadi wilayah aktivitas siswa, sehingga bisa menjadi tolak ukur dari keberhasilan siswa dalam mengikuti program Furudhul Ainiyah di madrasah, baik secara terstruktur maupun ekstra.

\footnotetext{
${ }^{55}$ Praslova, "Adaptation of Kirkpatrick's Four Level Model of Training Criteria to Assessment of Learning Outcomes and Program Evaluation in Higher Education."

${ }^{56}$ Wang and Chang, "Student Learning Outcome Assessment for an Information Organization Curriculum Based on the Kirkpatrick Framework."

${ }^{57}$ Mohamad Zarkhuan Zainol, Azmil Hashim, and Ahmad Yunus Kasim, "Application OfKirkpatrick Model ForEffectiveness OfIslamic Education Teacher Programme.”
} 
Kirkpatrick sebagai model harus bisa mengeksplorasi dari hasil akhir yang didapatkan peserta program Furudhul Ainiyah sebagai bahan pijakan dalam merencanakan teknis program selanjutnya. Maka usaha tersebut dapat dilakukan dengan cara ${ }^{58}$ : menggunakan grup sebagai kontrol jika hal tersebut sifatnya praktis, memberikan waktu untuk hasil yang ingin dicapai, mengukur sebelum dan sesudah program jika sifatnya praktis, melakukan penglangan dalam meguku di waktu yang tepat, memastikan data yang didapatkan berdasarkan bukti

\section{Penutup}

Program Furudhul Ainiyah yang menitik beratkan pada upaya pengembangan kognitif, afektif dan psikomotorik diperlukan sebuah proses yang efektif dan efesien, hal ini karena dasar munculnya disebabkan adanya gap materi Pendidikan Agama Islam antar tujuan dan hasil yang di dapatkan siswa, hal ini sesuai fakta yang terjadi berdasarkan penelitian yang dilakukan Kementerian Agama Provinsi Jawa Timur. Penting hal ini dilakukan biar tidak terjadi pengulangan program yang sama namun dengan proses dan hasil yang sama.

Perhatian tersebut tidak hanya pada tataran teknis pelaksanaan namun juga pada level evaluasi program tersebut. Terdapat banyak model evaluasi yang memungkinkan digunakan sebagai alat evaluasi termasuk Kirkpatrick Evaluation Model Mulai dari level 1, 2, 3 dan 4. Reaksi siswa yang tentunya baik karena berkenaan kehidupannya sebagai siswa madrasah yang tidak lepas dari Al-Qur'an Hadis, Fiqih dan Akhlak menjadi point keberhasilan dari penilaian level 1. Sedangkan pembelajaran yang efektif dengan diwujudkan dengan berkembangnya kognitif, afektif dan psikomotorik siswa sangat memungkinkan terjadi apalagi dengan panduan pembimbing yang profesional (level 2). Perubahan tersebut bukan hanya diwujudkan di dalam kelas namun juga dalam kehidupan keseharian siswa, baik di lingkungan rumah, asrama maupun di di madrasah sendiri dan inilah substansi dari level 3. Proses yang dilaksanakan di madrasah berupa sebuah program berdampak pada lingkungan siswa, yaitu keluarga siswa atau lingkungan siswa sehingga tercipta sebuah lingkungan yang berkarakter (level 4).

\footnotetext{
${ }^{58}$ Donald L Kirkpatrick and James D Kirkpatrick, Evaluating Training Programs.
} 


\section{Daftar Pustaka}

Abdi Shahshahani, Mahshid, Soheila Ehsanpour, Nikoo Yamani, Shahnaz Kohan, and Babak Hamidfar. 2015. "The Evaluation of Reproductive Health PhD Program in Iran: A CIPP Model Approach." Procedia - Social and Behavioral Sciences, 7th World Conference on Educational Sciences, 197 (July 25,): 88-97. https://doi.org/10.1016/j.sbspro.2015.07.059.

Adom, Dickson, Jephtar Adu Mensah, and Dennis Atsu Dake. 2020. "Test, Measurement, and Evaluation: Understanding and Use of the Concepts in Education." International Journal of Evaluation and Research in Education 9, no. 1 (March): 109-19.

Alliger, George M., Scott I. Tannenbaum, Winston Bennett, Holly Traver, and Allison Shotland. 1997. "A Meta-Analysis of the Relations Among Training Criteria." Personnel Psychology 50, no. 2 (): 341-58. https://doi.org/10.1111/j.17446570.1997.tb00911.x.

Arthur, Winfred, Travis Tubre', Don S. Paul, and Pamela S. Edens. 2003. "Teaching Effectiveness: The Relationship between Reaction and Learning Evaluation Criteria." Educational Psychology 23, no. 3 June: 275-85. https://doi.org/10.1080/0144341032000060110.

Aryadoust, Vahid. 2017 .'Adapting Levels 1 and 2 of Kirkpatrick's Model of Training Evaluation to Examine the Effectiveness of a Tertiary-Level Writing Course." Pedagogies: An International Journal 12, no. 2 (April 3,): 151-79. https://doi.org/10.1080/1554480X.2016.1242426.

Aziz, Shamsa, Munazza Mahmood, and Zahra Rehman. 2018. "Implementation of CIPP Model for Quality Evaluation at School Level: A Case Study." Journal of Education and Educational Development 5, no. 1 (May 30,): 189-206. https://doi.org/10.22555/joeed.v5i1.1553.

Bers, Trudy H. "The Role of Institutional Assessment in Assessing Student Learning Outcomes." New Directions for Higher Education 2008, no. 141 (2008): 31-39. https://doi.org/10.1002/he.291.

Donald L Kirkpatrick, and James D Kirkpatrick. 2008. Evaluating Training Programs. California: Berrett-Koehler Publishers,.

Enneking, Kory M., Graham R. Breitenstein, Amelia F. Coleman, James H. Reeves, Yishi Wang, and Nathaniel P. Grove. "The Evaluation of a Hybrid, General Chemistry Laboratory Curriculum: Impact on Students' Cognitive, Affective, and Psychomotor Learning." Journal of Chemical Education 96, no. 6 (June 11, 2019): 1058-67. https://doi.org/10.1021/acs.jchemed.8b00637.

Ewell, Peter T. "Accreditation and Student Learning Outcomes: A Proposed Point of Departure," n.d., 34.

Farjad, Shahrooz. "The Evaluation Effectiveness of Training Courses in University by Kirkpatrick Model (Case Study: Islamshahr University)." Procedia - Social and Behavioral Sciences 46 (January 1, 2012): 2837-41. https://doi.org/10.1016/j.sbspro.2012.05.573.

Fatima, Ghulam, Misbah Malik, Uzma Abid, and Dur-e-Nayab. "Early Childhood Special Education Program at the Outcome Phase: An Evaluation from Stake's Countenance Model Perspective." Bulletin of Education and Research 38, no. 2 (December 2016): 281-92. 
Griffin, Stephen, and Julian McDougall. "Despite Ourselves? Education Studies: Between Spirit and 'Passing On"” 2 (2009): 9.

Gunderman, Richard B., and Stephen Chan. "Kirkpatrick's Evaluation of Educational Programs and Its Relevance to Academic Radiology." Academic Radiology 22, no. 10 (October 1, 2015): 1323-25. https://doi.org/10.1016/j.acra.2015.07.005.

Hasan, Azman, Sharifah Nurulhuda Tuan Mohd Yasin, and Mohd Fauzi Mohd Yunus. "A Conceptual Framework for Mechatronics Curriculum Using Stufflebeam CIPP Evaluation Model." Procedia - Social and Behavioral Sciences, World Conference on Technology, Innovation and Entrepreneurship, 195 (July 3, 2015): 844-49. https://doi.org/10.1016/j.sbspro.2015.06.324.

Hidalgo, Luis, and Juan Arjona Fuentes. "The Development of Basic Competencies for Sustainability in Higher Education: An Educational Model by Luis Hidalgo, Juan Arjona Fuentes :: SSRN." Accessed June 11, 2020. https://papers.ssrn.com/sol3/papers.cfm?abstract_id=2486082.

Kennedy, Mary M. "How Does Professional Development Improve Teaching?" Review of Educational Research 86, no. 4 (December 2016): 945-80. https://doi.org/10.3102/0034654315626800.

Mohamad Zarkhuan Zainol, Azmil Hashim, and Ahmad Yunus Kasim. "Application OfKirkpatrick Model ForEffectiveness OfIslamic Education Teacher Programme." International Journal of Academic Research in Business and Social Sciences 7, no. 11 (2017): 361-68. https://doi.org/10.6007/IJARBSS/v7-i11/3468.

Ömer Gökhan ULUM. "Program Evaluation through Kirkpatrick's Framework." Pacific Business Review International 8, no. 1 (July 2015): 106-11.

Osman, David J., and Jayce R. Warner. "Measuring Teacher Motivation: The Missing Link between Professional Development and Practice." Teaching and Teacher Education 92 (June 2020): 103064. https://doi.org/10.1016/j.tate.2020.103064.

Paull, Megan, Craig Whitsed, and Antonia Girardi. "Applying the Kirkpatrick Model: Evaluating an Interaction for Learning Framework Curriculum Intervention," n.d., 18.

Praslova, Ludmila. "Adaptation of Kirkpatrick's Four Level Model of Training Criteria to Assessment of Learning Outcomes and Program Evaluation in Higher Education." Educational Assessment, Evaluation and Accountability 22, no. 3 (August 2010): 215-25. https://doi.org/10.1007/s11092-010-9098-7.

Razanaufal, Muhammad Wafi, and Donald Crestofel Lantu. "Evaluation of Leadership Training Program Using Kirkpatrick Model Case Study in Telkom Corporate University," 2019. https://doi.org/10.7176/rjfa/10-4-14.

Reio, Thomas G., Tonette S. Rocco, Douglas H. Smith, and Elegance Chang. "A Critique of Kirkpatrick's Evaluation Model." New Horizons in Adult Education and Human Resource Development 29, no. 2 (April 2017): 35-53. https://doi.org/10.1002/nha3.20178.

Rokhman, Fathur, M. Hum, Ahmad Syaifudin, and Yuliati. "Character Education for Golden Generation 2045 (National Character Building for Indonesian Golden Years)." Procedia - Social and Behavioral Sciences, 4th World Conference on Learning Teaching and Educational Leadership (WCLTA-2013), 141 (August 25, 2014): 1161-65. https://doi.org/10.1016/j.sbspro.2014.05.197.

Roselita Yusof. "Kelebihan Dan Kelemahan Model CIPP." Accessed June 7, 2020. https://id.scribd.com/doc/172730850/Kelebihan-Dan-Kelemahan-ModelCIPP\#: :text=2.\%20Kelemahan\%20model\%20cipp\%20Terlalu,ketimbang\%20me ngakui\%20kompleksitas\%20realitas\%20empiris. 
Rovai, Alfred P., Mervyn J. Wighting, Jason D. Baker, and Linda D. Grooms. "Development of an Instrument to Measure Perceived Cognitive, Affective, and Psychomotor Learning in Traditional and Virtual Classroom Higher Education Settings." The Internet and Higher Education 12, no. 1 (January 1, 2009): 7-13. https://doi.org/10.1016/j.iheduc.2008.10.002.

Sandifer, Mariama Cook, Dottie Martin, Lillian M. Range, and Thomas Fonseca. "Factors Associated with Programmatic Orientation and Supervision in Schools." Journal of $\begin{array}{lllll}\text { School Counseling } & 12 & \text { (2019). }\end{array}$ https://eric.ed.gov/?q=+supervision+of+implementation\&id=EJ1215231.

Smidt, Andy, Susan Balandin, Jeff Sigafoos, and Vicki A. Reed. "The Kirkpatrick Model: A Useful Tool for Evaluating Training Outcomes." Journal of Intellectual \& Developmental Disability 34, no. 3 (September 2009): 266-74. https://doi.org/10.1080/13668250903093125.

Stamm, Karen E., Lisa L. Harlow, and Theodore A. Walls. "An Introduction to Latent Variable Growth Curve Modeling: Concepts, Issues, and Applications (2nd Ed.)." Structural Equation Modeling: A Multidisciplinary Journal 14, no. 4 (October 23, 2007): 701-6. https://doi.org/10.1080/10705510701575644.

Thanabalan, T. Vanitha, Saedah Siraj, and Norlidah Alias. "Evaluation of a Digital Story Pedagogical Module for the Indigenous Learners Using the Stake Countenance Model." Procedia - Social and Behavioral Sciences, International Educational Technology Conference, IETC 2014, 3-5 September 2014, Chicago, IL, USA, 176 (February 20, 2015): 907-14. https://doi.org/10.1016/j.sbspro.2015.01.557.

Tian, Yongliang, $\mathrm{Hu}$ Liu, Jiao Yin, Mingqiang Luo, and Guanghui Wu. "Evaluation of Simulation-Based Training for Aircraft Carrier Marshalling with Learning Cubic and Kirkpatrick's Models." Chinese Journal of Aeronautics 28, no. 1 (February 1, 2015): 152-63. https://doi.org/10.1016/j.cja.2014.12.002.

Tim Pengembangan GERAMM. 2019. Buku Panduan Khusus Program Gerakan Ayo Membangun Madrasah. Surabaya: Kanwil Jatim,.

"UU No.20 Thn 2003 - Sistem Pendidikan Nasional." Accessed December 26, 2019. http://hukum.unsrat.ac.id/uu/uu_20_03.htm.

Wang, Mei-Ling, and Ai-Chi Chang. "Student Learning Outcome Assessment for an Information Organization Curriculum Based on the Kirkpatrick Framework," n.d., 18.

Zhang, Guili, Nancy Zeller, Robin Griffith, Debbie Metcalf, Jennifer Williams, Christine Shea, and Katherine Misulis. "Using the Context, Input, Process, and Product Evaluation Model (CIPP) as a Comprehensive Framework to Guide the Planning, Implementation, and Assessment of Service-Learning Programs." Journal of Higher Education Outreach and Engagement 15, no. 4 (December 2011): 57-84. 